\title{
Studies on Citrus Melanose and Citrus Stem-End Rot by Diaporthe citri (Faw.) Wolf. Part 8. Distribution of Pathogen Inhibitory Substances in Citrus Tissues
}

\author{
Yasuo Homma* and Yutaka ARImoto*
}

\begin{abstract}
Even if citrus fruits are severely affected by melanose, they do not rot. This is considered to be due to some pre-inhibitins or phytoalexins induced in their tissues. The effect of extracts from leaves, twigs, fruit peel and fruit vesicles of citrus plants (satsuma mandarin and natsudaidai) on pycnospore germination, germ tube elongation and disease development was examined. Among them, the peel extract showed the greatest inhibitory effect on pycnospore germination and germ tube elongation, followed by the extracts from leaf, fruit vesicle and twig in that order. A similar examination was carried out to prove the presence of inhibitory substances in the vascular bundle system of the fruit. The extract from the tissues directly under the disk had the greatest inhibitory effect, followed by that from the stem button. The extract from the vascular bundle in the fruit also had an inhibitory effect. When the inhibitory effects of extracts from exocarps, mesocarps, endocarps and vesicles of natsudaidai fruit were compared with each other, the extracts from vesicle and exocarp had an inhibitory effect at a 100time dilution, but those from others did not have at the same concentration. The inhibitory effect of vesicle extract against pycnospore germination and germ tube elongation decreased with the period of fruit storage after harvest. Extracts from fruit peel and vesicle inhibited melanose even if they were diluted 100-1,000 times, and the 100-time dilution also effective in controlling black rot, gray mold, anthracnose, and phoma rot when the fruit was treated with the 100 times diluted extract before inoculation.
\end{abstract}

(Received May 11, 1987)

Key words: citrus, Diaporthe citri, inhibitory substance, melanose, pre-inhibitin, stem-end rot.

\section{INTRODUCTION}

Both citrus melanose and citrus stem-end rot are caused by the same pathogen, Diaporthe citri (Faw.) Wolf. The former occurs on new shoots, leaves and fruit while the latter develops on fruit during storage. D. citri is a rain-borne pathogen, and in field it induces citrus melanose on fruit from June to October under the conditions of $10 \mathrm{~mm}$ or more rainfall, or high humidity at $20 \mathrm{C}$ or higher, $12 \mathrm{hr}$ or longer ${ }^{10}$ ). The surface of the fruit is blemished by melanose, but the fruit does not rot at that time.

Some researchers have studied on the mechanisms of the development of both diseases, but some unknown factors still remain. There are some reports on the pycnospore germination and subsequent penetration ${ }^{1,10,12,14}$. In the SEM observation, it was found that pycnospore germination and penetration to the host tissues start 5 and $8 \mathrm{hr}$ after inoculation, respectively. Penetration rate was $7 \%$ on both the upper and lower leaf surfaces ${ }^{1)}$. After infection,

* The Institute of Physical and Chemical Research (RIKEN), 2-1 Hirosawa, Wako, Saitama, 351-01 Japan 理化学研究所 
the pathogen was arrested in the epidermal cells of the host, because the infected cells granulated and turned brown in color ${ }^{3)}$. Host plant cells have pre-inhibitins ${ }^{7-9)}$, and may induce a phytoalexin and plant hormones and accelerated their cell-division to protect themselves ${ }^{2-5}$.

The causal fungus penetrates into pedicels and moves to the end of the pedicels, where it remains after harvesting. Three interesting facts associated with the development of citrus stem-end rot have been noticed. First, citrus melanose occurs on fruit whereas it is on the tree without causing rotting. Second, the pathogen which invaded the fruit from the pedicels or twigs is transmitted to the stem-end where it survives for a long period of time up to 9 months. Third, the fruit rots during the later period of storage.

Bahgat ${ }^{(6)}$ clarified enzymal activities related to stem-end rot and Homma et al..$^{11)}$ described the penetration sites and mode of hyphal penetration to the fruit in connection with the development of stem-end rot. This investigation was made to clarify the distribution of pre-inhibitins in citrus tissues.

\section{MATERIALS AND METHODS}

\section{Inhibitory effects of extracts from various parts of citrus trees on pycnospore germination and germ tube elongation.}

1. Each $200 \mathrm{~g}$ of fresh leaves (this year), twigs (this year), fruit peel and fruit vesicles of satsuma mandarin (Citrus unshiu Marc.) was extracted in the middle of November as described in Fig. 1. The solvent in the extracts was completely evaporated off, $10 \mathrm{mg}$ of residue as formulated concentrates (FC) was diluted with distilled water to appropriate concentrations. The final concentration was achieved by mixing with the same volume of $D$. citri pycnospore suspension containing $5 \%$ fructose. The mixtures were dropped on a slide glass and incubated at $25 \mathrm{C}$ for 24 or $48 \mathrm{hr}$ as described previously ${ }^{8}$. Then, germination and germ tube elongation were observed under an optical microscope.

2. The citrus tissues from stem-end to core fruit where the pathogen is located were divided into three parts, i.e., the stem button, the tissue under the disk and vascular bundles. From

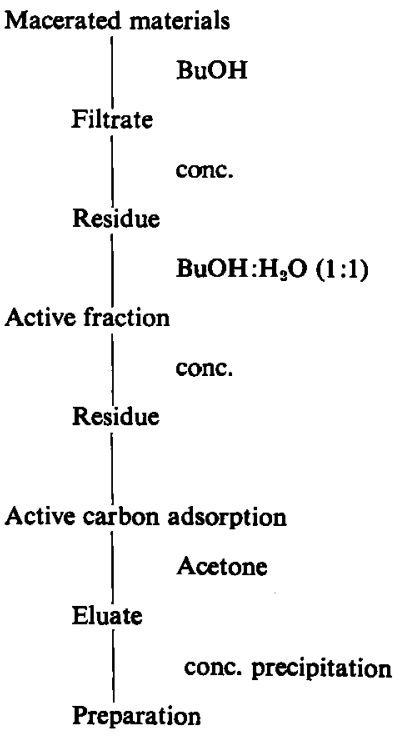

Fig. 1. Procedure of extraction. 
early October to January, each $100 \mathrm{~g}$ of the above three parts was collected from 1,500 satsuma mandarin fruits, macerated, extracted and then tested for their influence on pycnospore germination and germ tube elongation by the above-mentioned method.

3. As shown in Fig. 2, citrus fruit consists of exocarp, mesocarp, endocarp and vesicle ${ }^{13}$. Natsudaidai (Citrus natsudaidai Hayata) fruit, having thick peel, was used in this experiment in the middle of April. Three hundred and fifty grams of exocarp, $150 \mathrm{~g}$ of mesocarp, $50 \mathrm{~g}$ of endocarp, and $350 \mathrm{~g}$ of vesicle were macerated separately and extracted. Tests were carried out by the above-mentioned method.

4. As stem-end rot occurs at the later period of fruit storage, seasonal variances of the inhibitory effect of the extracts were investigated. Each $200 \mathrm{~g}$ of fruit peel and fruit vesicle of satsuma mandarin was extracted every a month from October to April. Tests were carried out by the above-mentioned method. The inhibitory effects were compared in percentage of stem-end rot occurrence ${ }^{11)}$.

\section{Effects of extracts from various parts of citrus trees on development of some citrus diseases}

1. Absorbent cotton, $1 \mathrm{~cm} \times 1 \mathrm{~cm}$ square in size, was dipped in peel extract dilutions and stuck for 2 days on the surface of satsuma mandarin and natsudaidai fruits grown in a glasshouse. Then another absorbent cotton dipped in the pycnospore suspension of Diaporthe citri (concentration: about 100 pycnospores under $150 \times$ magnification of an optical microscope) was stuck on the same place previously treated with an extract. The fruit was incubated in a moist chamber at $25 \mathrm{C}$ for 2 days. Citrus melanose spots were counted 2 weeks after inoculation.

2. As shown in Fig. 3, satsuma mandarin fruit picked in late November were pricked by a needle. A 100-time dilution of the extract from satsuma mandarin fruit peel was applied to the wounded parts of the fruit peel as mentioned above. Suspensions of Penicillium digitatum conidia (concentration: about 50 conidia under $150 \times$ magnification of an optical microscope), and mycelial suspension of Alternaria citri, Botrytis cinerea, Colletotrichum gloeosporioides and Phoma erratica var. mikan were dropped on the parts treated with extract, and incubated in a moist chamber at $25 \mathrm{C}$ for 4 days. The number of disease lesions was counted about a month later.

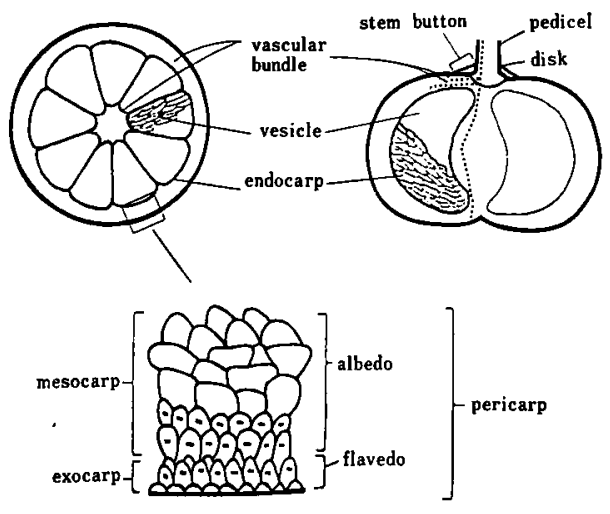

Fig. 2. Cross and longitudinal diagram of citrus fruit.

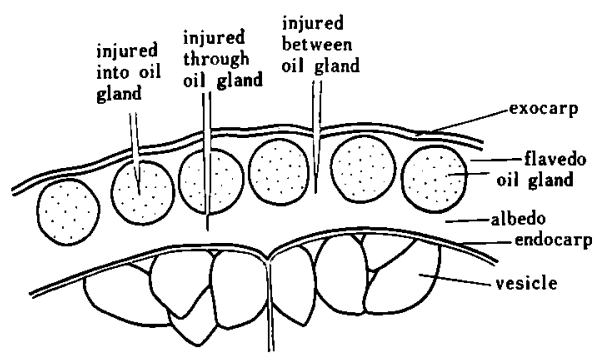

Fig. 3. Illustration of various methods of prick to the pericarp of citrus fruit. 


\section{RESULTS}

\section{Inhibitory effects of extracts from various parts of citrus trees on pycnospore germination and germ tube elongation}

1. Inhibitory effect of extracts from various parts of citrus trees on pycnospore germination

As shown in Table 1, among the four extracts tested, fruit peel of satsuma mandarin has the highest inhibitory effect. The extract completely inhibited pyenospore germination even at 1,000-time dilution. The second most effective fraction was that of the leaf extract, which inhibited pycnospore germination at 100 -time dilution. The extract from the vesicle could not completely inhibited germination at 100 -time dilution, and that from the twigs had no inhibitory effect at the same concentration.

2. Inhibitory effect of extracts from various parts of fruit on pycnospore germination

As shown in Table 2, a 1,000-time dilution of each extract prepared from natsudaidai fruit did not inhibit pycnospore germination at all. A 100-time dilution of mesocarp and endocarp extracts did not suppress the germination and germ tube elongation, but exocarp and vesicle extracts inhibited both germination and elongation about $50 \%$ at the same dilutions.

The stem button and tissues under the disk at the citrus stem-end and the subsequent vascular bundles inside satsuma mandarin fruit allow the passage of the pathogen hyphae that cause citrus stem-end rot. It was examined whether extracts from those vascular bundle systems had an inhibitory effect. As shown in Table 3, a 10-time dilution of extract from the stem button and the tissues under disk completely inhibited pycnospore germination, and the same dilution of the extract from subsequent vascular bundles inhibited it nearly $100 \%$. A 100 -time dilution of the extract from the tissues under the disk showed inhibitory effect on germ tube elongation.

Table 1. Effect of the extracts from various parts of satsuma mandarin on pycnospore germination and germ tube elongation of $D$. citri

\begin{tabular}{lcrrrr}
\hline \hline Extract & Treatment & $\begin{array}{c}\text { Pycnospore } \\
\text { germination } \\
(\%)\end{array}$ & $\begin{array}{r}\text { Inhibition } \\
(\%)\end{array}$ & $\begin{array}{r}\text { Index of } \\
\text { germ tube } \\
\text { length })\end{array}$ & $\begin{array}{c}\text { Inhibition } \\
(\%)\end{array}$ \\
\hline \multirow{2}{*}{ Leaf } & FC $\left.) \times 10^{4}+\mathrm{Fe}\right)$ & 100 & 0 & 54 & 10 \\
& FC $\times 10^{3}+\mathrm{F}$ & 100 & 0 & 60 & 0 \\
\hline \multirow{3}{*}{ Fruit peel } & FC $\times 10^{2}+\mathrm{F}$ & 0 & 100 & 0 & 100 \\
\hline Twig & FC $\times 10^{4}+\mathrm{F}$ & 100 & 0 & 13 & 78 \\
\hline Fruit vesicle & FC $\times 10^{3}+\mathrm{F}$ & 0 & 100 & 0 & 100 \\
\hline Distilled water & FC $\times 10^{2}+\mathrm{F}$ & 0 & 100 & 0 & 100 \\
\hline
\end{tabular}

a) Index of germ tube length $(X)$ was calculated by the following equation, $X=\frac{1 n_{1}+2 n_{3}+3 n_{3}+4 n_{4}+5 n_{5}}{5 N} \times 100$, where $n_{1}-n_{5}$ indicate the number of pycnospores with the germ tube length equal to, less than four times, less than ten times, less than fifteen times and more than fifteen times of the major axis of the pycnospore, respectively. Observation was made $24 \mathrm{hr}$ after incubation.

b) FC: formulated concentrate (Sampling date: November 16).

c) F means containing $5 \%$ fructose. 
Table 2. Effect of the extracts from various parts of natsudaidai fruit tissues on pycnospore germination and germ tube elongation of $D$. citri

\begin{tabular}{lccccr}
\hline Extract & Treatment & $\begin{array}{c}\text { Pycnospore } \\
\text { germination } \\
(\%)\end{array}$ & $\begin{array}{c}\text { Inhibition } \\
(\%)\end{array}$ & $\begin{array}{r}\text { Index of } \\
\text { germ tube } \\
\text { length })\end{array}$ & $\begin{array}{c}\text { Inhibition } \\
(\%)\end{array}$ \\
\hline Exocarp & FC $\left.) \times 10^{3}+F^{(}\right)$ & 100 & 0 & 60 & 0 \\
& FC $\times 10^{2}+\mathrm{F}$ & 67 & 33 & 33 & 45 \\
\hline Mesocarp & FC $\times 10^{3}+\mathrm{F}$ & 100 & 0 & 80 & -33 \\
\hline \multirow{2}{*}{ Endocarp } & FC $\times 10^{2}+\mathrm{F}$ & 100 & 0 & 80 & -33 \\
\hline \multirow{2}{*}{ Vesicle } & FC $\times 10^{3}+\mathrm{F}$ & 100 & 0 & 47 & 22 \\
& FC $\times 10^{2}+\mathrm{F}$ & 100 & 0 & 80 & -33 \\
\hline Distilled Water & FC $\times 10^{3}+\mathrm{F}$ & 100 & 0 & 80 & -33 \\
\end{tabular}

a), b) and c) See footnote of Table 1 (Sampling date: April 17).

Table 3. Effect of the extracts of disks, tissues under disks and vascular bundles of satsuma mandarin fruit on pycnospore germination and germ tube elongation of $D$. citri

\begin{tabular}{|c|c|c|c|c|c|}
\hline Extract & Treatment & $\begin{array}{c}\text { Pycnospore } \\
\text { germination } \\
(\%)\end{array}$ & $\begin{array}{c}\text { Inhibition } \\
(\%)\end{array}$ & $\begin{array}{c}\text { Index of } \\
\text { germ tube } \\
\text { lengtha) }\end{array}$ & $\begin{array}{c}\text { Inhibition } \\
(\%)\end{array}$ \\
\hline & $F(b) \times 10^{3}+F(c)$ & 100 & 0 & 67 & 1 \\
\hline \multirow[t]{2}{*}{ Stem buttcn } & $\mathrm{FC} \times 10^{2}+\mathrm{F}$ & 100 & 0 & 87 & -28 \\
\hline & $\mathrm{FC} \times 10+\mathrm{F}$ & $\mathbf{0}$ & 100 & 0 & 100 \\
\hline \multirow{3}{*}{ Tissue under disk } & $\mathbf{F C} \times 10^{3}+\mathrm{F}$ & 100 & 0 & 56 & 18 \\
\hline & $\mathrm{FC} \times 10^{2}+\mathrm{F}$ & 95 & 5 & 38 & 44 \\
\hline & $\mathbf{F C} \times 10+F$ & 0 & 100 & 0 & 100 \\
\hline \multirow{3}{*}{ Vascular bundle } & $x 10^{3}+F$ & 100 & 0 & 80 & -18 \\
\hline & $\mathrm{FC} \times 10^{2}+\mathrm{F}$ & 100 & 0 & 100 & -47 \\
\hline & $F C \times 10+F$ & 3 & 97 & 11 & 24 \\
\hline Distilled water & $+F$ & 100 & - & 68 & - \\
\hline
\end{tabular}

a), b) ard c) See Table 1 (Sampling date: October 7).

3. Seasonal variances of fruit peel or vesicle extract in inhibitory effect on pycnospore germination

The tissues of post-harvest fruit of satsuma mandarin were used periodically for extraction. The results obtained through experiments over two years were shown in Fig. 4. The extract from citrus fruit vesicle in October was effective in suppressing pycnospore germination of D. citri. A similar extract collected from vesicle at the end of February was less effective, and that of in the middle of April had no ability to inhibit pycnospore germination and germ tube elongation. On the other hand, the extract from fruit peel at any season completely inhibited pycnospore germination. On the storage tests, stem-end rot began to occur in the middle February and increased with the length of storage.

\section{Effects of extracts from various parts of citrus trees on development of some kinds of citrus diseases}

1. Effect of extracts from leaves, twigs, fruit peel and vesicles on occurrence of melanose As shown in Table 4, in the case of satsuma mandarin fruit, 100- to 1,000-time dilution 


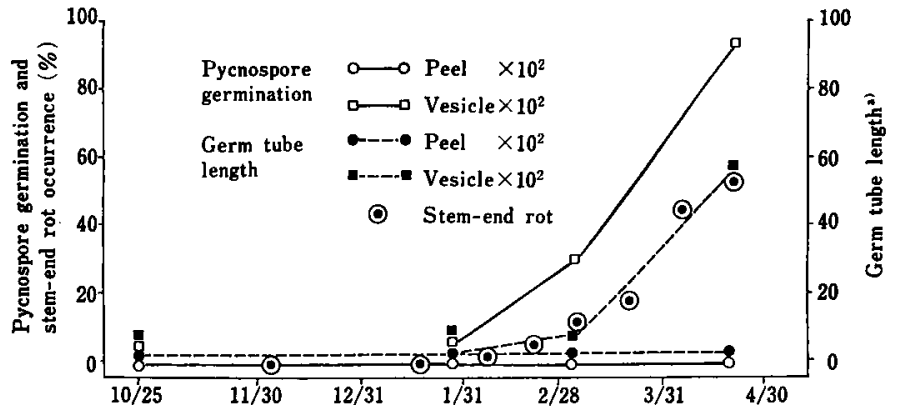

Fig. 4. The relationship between inhibitory effect of storage fruit extracts on pycnospore germination and germ tube elongation of $D$. citri and stem-end rot occurrence.

Table 4. Effect of the extracts from various parts of satsuma mandarin on occurrence of citrus melanose on satsuma mandarin and natsudaidai fruit

\begin{tabular}{|c|c|c|c|}
\hline \multirow{2}{*}{ Extract } & \multirow{2}{*}{ Treatment } & \multicolumn{2}{|c|}{ Preventive value $(\%)$} \\
\hline & & satsuma & natsudaidai \\
\hline \multirow{3}{*}{ Leaf } & $F^{(a)} \times 10^{4}+F^{(b)}$ & 92 & 47 \\
\hline & $\mathrm{FC} \times 10^{3}+\mathrm{F}$ & 100 & 65 \\
\hline & $\mathrm{FC} \times 10^{2}+\mathrm{F}$ & 99 & 94 \\
\hline \multirow{3}{*}{ Fruit peel } & $\mathrm{FC} \times 10^{4}+\mathrm{F}$ & 95 & 41 \\
\hline & FC $\times 10^{3}+F$ & 98 & 98 \\
\hline & $\mathrm{FC} \times 10^{2}+\mathrm{F}$ & 100 & 100 \\
\hline Twig & $\mathbf{F C} \times 10^{2}+\mathrm{F}$ & 80 & 69 \\
\hline Fruit vesicle & FC $\times 10^{2}+F$ & 92 & 0 \\
\hline Distilled water & $+\mathbf{F}$ & 0 & 0 \\
\hline
\end{tabular}

a) and b) See Table 1 (Sampling date: November 16).

of fruit peel extract inhibited occurrence of melanose almost completely and leaf extract also showed marked inhibitory effect. A 100-time dilution of the extracts from vesicle and twig had inhibitory effects of about 90 and $80 \%$, respectively. In the case of natsudaidai fruit, the 100- to 1,000-time dilutions of fruit peel extract and a 100-time dilution of leaf extract had $90 \%$ or more inhibitory effect against melanose. Extracts other than those from the vesicle had an inhibitory effect of more than $40 \%$. There were some different results between two citrus species used for the inoculation. In addition, the inhibitory effect against melanose occurrence was stronger than that against pycnospore germination.

2. Effects of fruit peel extract on some post-harvest diseases

As shown in Table 5, when a fruit injured into oil gland was inoculated with a pycnospore suspension of $D$. citri, the rotting did not occur. In contrast, however, the disease developed when inoculation was made of the site through or between oil glands. In the case of $P$. digitatum inoculation, only a few materials rotted after inoculation by every method. In the case of $A$. citri inoculation, the relationship between inoculation method and disease occurrence was not clear. However, treatment with the extract of fruit peel inhibited disease occurrence.

In the case of $B$. cinerea inoculation, $30-40 \%$ of the fruit rotted. From this result, it seemed that the fungus entered through injuries. When the fruit was previously treated with the extract, rotting never occurred. 
Table 5. Effect of the extract from satsuma mandarin fruit peel on infection of some post-harvest diseases

\begin{tabular}{|c|c|c|c|c|c|c|}
\hline \multirow[b]{2}{*}{$\begin{array}{l}\text { Infection site } \\
\text { by needle pricking a ) }\end{array}$} & \multicolumn{6}{|c|}{ Inoculum } \\
\hline & $\begin{array}{l}\text { Diaporthe } \\
\text { citri }\end{array}$ & $\begin{array}{l}\text { Penicillium } \\
\text { digitatum }\end{array}$ & $\begin{array}{c}\text { Alternaria } \\
\text { citri }\end{array}$ & $\begin{array}{c}\text { Botrytis } \\
\text { cinerea }\end{array}$ & $\begin{array}{l}\text { Colletotrichum } \\
\text { gloeosporioides }\end{array}$ & $\begin{array}{c}\text { Phoma } \\
\text { erratica } \\
\text { var. mikan }\end{array}$ \\
\hline \multicolumn{7}{|c|}{ Treatment of fruit peel extracte) } \\
\hline Into oil gland & - & $\left.1 / 14^{b}\right)$ & $0 / 7$ & $0 / 10$ & $0 / 12$ & $0 / 11$ \\
\hline Through oil gland & - & $2 / 14$ & $0 / 7$ & $0 / 10$ & $3 / 12$ & $3 / 11$ \\
\hline Between oil gland & - & $2 / 14$ & $0 / 7$ & $0 / 10$ & $0 / 12$ & $2 / 11$ \\
\hline Total number & 一 & $5 / 42$ & $0 / 21$ & $0 / 30$ & $3 / 36$ & $5 / 33$ \\
\hline \multicolumn{7}{|l|}{ None-treatment } \\
\hline Into oil gland & $0 / 10$ & $2 / 14$ & $2 / 7$ & $4 / 10$ & $1 / 12$ & $1 / 11$ \\
\hline Through oil gland & $3 / 10$ & $3 / 14$ & $1 / 7$ & $3 / 10$ & $6 / 12$ & $3 / 11$ \\
\hline Between oil gland & $6 / 10$ & $0 / 14$ & $0 / 7$ & $3 / 10$ & $3 / 12$ & $6 / 11$ \\
\hline Total number & $9 / 30$ & $5 / 42$ & $3 / 21$ & $10 / 30$ & $10 / 36$ & $10 / 33$ \\
\hline
\end{tabular}

a) See Fig. 3.

b) Number of diseased holes/number of wounded holes.

c) Formulated concentrate $\times 10^{2}$ was treated in early December.

When fruit were inoculated with $C$. gloeosporioides at the site injured through oil gland, many of the fruit rotted. Disease development was inhibited when the fruit was previously treated with extract.

In the case of inoculation of Phoma erratica var. mikan, fruit pricked between oil glands was most susceptible. When fruit was treated with the extract before inoculation, the total number of rotted fruit decreased by $50 \%$.

\section{DISCUSSION}

We have investigated the mechanisms of citrus melanose development on young leaves or fruit and the mode of stem-end rot on post-harvest fruit. As we reported previously on the existence of some pre-inhibitins $^{7-9)}$ or the formation of some phytoalexins ${ }^{4,5}$, we have now studied the distribution of these pre-inhibitins in citrus tissues by testing for inhibitory effects of the extract on pycnospore germination, and occurrence of citrus melanose and other diseases.

Among citrus twigs (newly developed), leaves (newly developed), vesicles and peel in midNovember, an extract of twigs had the lowest inhibitory effect, and those from vesicle, peel and leaves were $2.5,10-100$ and 10 times stronger respectively than from the twigs with regard to the inhibitory effect on pycnospore germination and germ tube elongation of $D$. citri.

When compared to extract from peel and exocarp, the extracts from the fruit had large inhibitory effects. The 100-time dilution of mesocarp and endocarp extracts did not inhibit pycnospore germination.

Among vascular bundle systems, an extract from the tissues under the disk had the greatest effect and stem button extract also had a strong inhibitory effect. Leaf, fruit peel, twig and fruit vesicle extracts showed a marked inhibitory effect on melanose occurrence.

The extract from fruit peel was also effective in controlling some types of fruit rot caused by Botrytis cinerea, Colletotrichum gloeosporioides, Alternaria citri and Phoma erratica var. mikan. Therefore, citrus tissues have inhibitory substances not only in the fruit peel and leaves but also in the vascular bundle system from the stem-end to the core fruit. These facts indicate that the citrus plant protects itself from the invasion of pathogens. 
The inhibitory activity of the extract from fruit vesicle decreased with increase of the storage period of the fruit after harvesting. On the other hand, occurrence of stem-end rot increased with the length of the storage period of the fruit. Since the decrease of inhibitory activity and occurrence of stem-end rot correlated with each other, inhibitory activity by vesicle extract is deeply related to inhibition of stem-end rot development.

\section{Literature cited}

1. Arimoto, Y., Homma, Y. and Misato, T. (1980). Ann. Phytopath. Soc. Japan 46: 575-581.

2. Arimoto, Y., Homma, Y. and Misato, T. (1981). Proc. Int. Soc. Citriculture, pp. 374-379.

3. Arimoto, Y., Homma, Y. and Misato, T. (1982). Ann. Phytopath. Soc. Japan 48: 559-569.

4. Arimoto, $Y$. and Homma, Y. (1986). Ibid. 52: 683-689.

5. Arimoto, Y., Homma, Y. and Ohsawa, T. (1986). Ibid. 52: 620-625.

6. Bahgat, M. (1928). Hilgardia 3: 153-181.

7. Homma, Y. (1975). Kagaku 45: 538-545.

8. Homma, Y., Arimoto, Y. and Misato, T. (1979). Ann. Phytopath. Soc. Japan 45: 9-16.

9. Homma, Y., Arimoto, Y. and Misato, T. (1981). Proc. Int. Soc. Citriculture, pp. 370-374.

10. Homma, Y. and Yamada, S. (1969). Bull. Hortic. Res. Stn. Japan B9: 85-97.

11. Homma, Y. and Yamada, S. (1969). libid. B9: 99-115.

12. Kuramoto. T. and Yamada, S. (1975). Bull. Fruit Tree Res. Stn. B2: 75-86.

13. Shichijo, T. (1981). The collection of citrus technical terms (Okitsu Branch ed.). Fruit Tree Res. Stn. 87.

14. Ushiyama, K. (1976). Bull. Kanagawa Hortic. Exp. Stn. 23: 11-18.

\section{和 文 摘 要}

本間保男・有本 裕：Diaporthe citriによるカンキツ黑点病ならびに軸腐病に関する研究 (第 8 報) カン キツ組織に拈ける病原菌の柄胞子発芽抑制物質の分布

カンキッ果実は黒点病の激しい被害を受けてる腐敗に至らない。これは果皮に存在する先在性抗菌物質と ファイトアレキンンの誘導などによるものと考えられる。種々の器官と果実内組織からの溶媒抽出液とを用 いて柄胞子発芽、発芽管伸長ならびに発病抑制効果を検討した。莱, 枝, 果皮, 果肉の各抽出夜のなかで, 柄胞子発芽およひ発芽管伸長抑制の最も強かったのは果皮抽出液であり，ついで集，果肉，枝の順であった。 果実果梗基部から果実内部の維管束系を同様に調べたところ, 果盤下組織からの抽出液の抑制力が強く，つ いで果盤抽出液であった。しかし果実内部の維管束抽出液でも抑制効力を有していた。ナッミカンの外果 皮，中果皮，じょうのうおよび果肉からの各抽出液の活性を比較したところ，果肉おょび外果皮抽出液はそ の100 倍希釈液まで抑制したが, 注かの部位からの抽出液は抑制しなかった。収權後 2 カ月以上経過した果 実では，果肉抽出液の抑制力は徐々に低下した。果皮からの抽出液は，102倍では黒病病，灰色かび病，炭 そ病，黒斑病に対して抑制効果を示し，102 $10^{4}$ 倍に希积しても黑点病に対して抑制効果を示した。 